\title{
Chemical characteristics assigned to trajectory clusters during the MINOS campaign
}

\author{
M. Traub ${ }^{1}$, H. Fischer ${ }^{1}$, M. de Reus ${ }^{1}$, R. Kormann ${ }^{1}$, J. Heland ${ }^{2}$, H. Ziereis ${ }^{2}$, H. Schlager ${ }^{2}$, R. Holzinger ${ }^{1}$, J. Williams ${ }^{1}$, \\ C. Warneke ${ }^{3}$, J. de Gouw ${ }^{3}$, and J. Lelieveld ${ }^{1}$ \\ ${ }^{1}$ Max Planck Institute for Chemistry, Mainz, Germany \\ ${ }^{2}$ Institute for Atmospheric Physics, German Aerospace Center, DLR, Oberpfaffenhofen, Germany \\ ${ }^{3}$ NOAA Aeronomy Laboratory, Boulder, Colorado, USA
}

Received: 26 November 2002 - Published in Atmos. Chem. Phys. Discuss.: 10 January 2003

Revised: 19 March 2003 - Accepted: 2 April 2003 - Published: 17 April 2003

\begin{abstract}
During the Mediterranean Intensive Oxidant Study (MINOS) in August 2001 a total of 14 measurement flights were performed with the DLR Falcon jet aircraft from Heraklion, Crete. One objective of this campaign was to investigate the role of long-range transport of pollutants into the Mediterranean area. An analysis of 5-day back trajectories indicates that in the lower troposphere $(0-4 \mathrm{~km})$ air masses originated from eastern and western Europe, in the mid-troposphere $(4-8 \mathrm{~km})$ from the North Atlantic Ocean region and in the upper troposphere $(8-14 \mathrm{~km})$ from North Atlantic Ocean/North America (NANA) as well as South Asia. We allocated all back trajectories to clusters based on their ending height and source region. The mixing ratios of ozone, nitrogen oxide, total reactive oxidized nitrogen $\left(\mathrm{NO}_{\mathrm{y}}\right)$, formaldehyde, methanol, acetonitrile, acetone, peroxyacetyl nitrate (PAN), carbon dioxide, carbon monoxide and methane measured along the flight tracks are examined in relation to the different cluster trajectories. In the lower troposphere the mean trace gas mixing ratios of the eastern Europe cluster trajectories were significantly higher than those from western Europe. In the upper troposphere air from the NANA region seems to be influenced by the stratosphere, in addition, air masses were transported from South Asia, being influenced by strong convection in the Indian monsoon.
\end{abstract}

\section{Introduction}

A large number of chemical measurements was made from the DLR Falcon aircraft during the Mediterranean Intensive Oxidant Study (MINOS) flights in August 2001. The flight tracks of this experiment are shown in Fig. 1. The measurements were designed to explore the role of long-range transport of pollutants into the Mediterranean basin. As a result of

Correspondence to: $\mathrm{M}$. Traub

(mtraub@mpch-mainz.mpg.de) the regional meteorological conditions (cloud-free, high temperatures and intense solar radiation), photochemistry can be very active (Kouvarakis et al., 2000), and the area is sensitive to air pollution. An overview is given by Lelieveld et al. (2002).

Backward trajectory analysis has become a widely used method for interpretation of trace gas measurements in relation to large-scale air mass transport (Moody et al., 1995). The trajectories can be categorized into particular clusters to characterize different types of air masses. In most cases, the origin of the air masses and their transport routes have been used as the main criteria for clustering. By assuming that the chemical composition changes at the same rate along all transport paths, the variability in the measured trace gas concentrations can be explained in terms of the trajectory origin and emission influences along the route (Pochanart et al., 2001).

It should be mentioned, however, that the implicit assumption that the trajectories accurately represent transport pathways may sometimes be incorrect. There are many uncertainties involved in the measurements of the meteorological conditions, the generation of reanalysis data with help of the observed parameters and assimilation methods, the interpolation of the wind in time and space, and also the representation of small-scale effects (e.g. convection) in the meteorological data. Stohl (1998) estimated the accuracy of computed trajectories with position errors up to $20 \%$ of the travel distance. Nevertheless, trajectories provide a useful tool to characterize patterns in the large-scale motion.

In the next Section a short overview of the measurement techniques on board the Falcon is given. In Section 3 a general overview of the large-scale circulation over the Mediterranean area is presented. Section 4 subsequently describes the model used, and Section 5 presents the three-dimensional trajectory analysis and the chemical characteristics of the different trajectory clusters. Section 6 concludes by summarizing the relative importance of different source regions. 


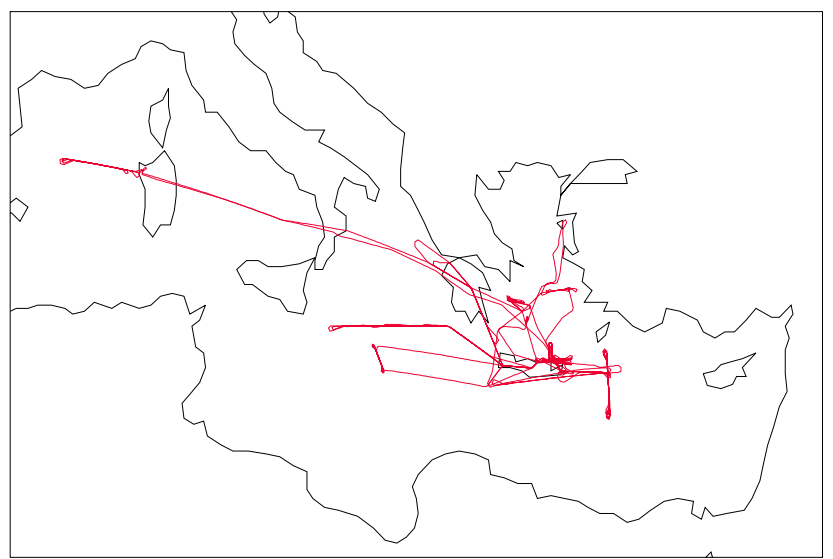

Fig. 1. Flight tracks of the DLR Falcon aircraft over the eastern and central Mediterranean Sea during MINOS in August 2001.

\section{Measurement techniques}

$\mathrm{CO}, \mathrm{CO}_{2}, \mathrm{CH}_{4}, \mathrm{CH}_{3} \mathrm{OH}, \mathrm{CH}_{3} \mathrm{COCH}_{3}, \mathrm{CH}_{3} \mathrm{CN}$, PAN and $\mathrm{HCHO}$ were measured by the Max Planck Institute for Chemistry, Mainz, Germany.

For $\mathrm{CO}, \mathrm{CO}_{2}$ and $\mathrm{CH}_{4}$ a Tunable Diode Laser Absorption Spectrometer (TDLAS), with a time resolution of $6 \mathrm{~s}$, was used. The precision was $1.5 \mathrm{ppm}$ for $\mathrm{CO}_{2}, 1.5 \mathrm{ppbv}$ for $\mathrm{CO}$ and $16.5 \mathrm{ppb}$ for $\mathrm{CH}_{4}$ and the average accuracy was $1 \%$ for all species. A detailed description of the instrument can be found in Wienhold et al. (1998).

The mixing ratios of $\mathrm{CH}_{3} \mathrm{OH}, \mathrm{CH}_{3} \mathrm{CN}, \mathrm{CH}_{3} \mathrm{COCH}_{3}$ and PAN were measured using proton-transfer reaction mass spectrometry (PTR-MS). The accuracy for $\mathrm{CH}_{3} \mathrm{OH}$ was $20 \%$, for $\mathrm{CH}_{3} \mathrm{CN}$ and $\mathrm{CH}_{3} \mathrm{COCH}_{3} 15 \%$. The measurement technique is described in detail by Lindinger et al. (1998) and by Holzinger et al. (2003).

The measurement of $\mathrm{HCHO}$ was based on the fluorimetric detection of the Hantzsch reaction product, as originally described by Belman (1963). The instrument's noise is about $1.5 \%$ of the concentration reading up to concentrations of about 20 ppbv. A detailed description of these measurements is given by Kormann et al. (2003).

$\mathrm{NO}, \mathrm{NO}_{\mathrm{y}}$ and $\mathrm{O}_{3}$ were measured by the DLR Oberpfaffenhofen, Germany. For $\mathrm{NO}$ and $\mathrm{NO}_{\mathrm{y}}$ a chemiluminescence detector was used. The accuracy of the $\mathrm{NO}$ and $\mathrm{NO}_{\mathrm{y}}$ measurements is $5 \%$ and $15 \%$, respectively, for concentration levels of 1 ppbv. $\mathrm{O}_{3}$ is measured with the UV absorption technique with an accuracy of 5\%. Details of the instruments are given in Schlager et al. (1997) and Ziereis et al. (2000).

\section{Meteorological situation}

The mean flow in the extratropics is characterized by the westerlies. The geographical position of the Azores High and the Icelandic Low can modify the zonal flow and therefore have a great impact on the weather in Central Europe and the Mediterranean region. When the High and Low are strongly developed and therefore the pressure gradient is relatively high, relatively moist air masses from the Atlantic Ocean are transported to Europe. In the alternate case, the zonal air flow is weak and meridional and blocking weather systems over Central Europe prevail. The interannually varying pressure gradient between the Icelandic Low and Azores High is generally known as the North Atlantic Oscillation (NAO). It is linked to the general atmospheric and the oceanic circulation systems, the latter being affected by the formation of cold bottom waters in the Arctic ocean and the influx of salty water from the Mediterranean Sea through the Strait of Gibraltar (Bolle, 2003). By definition, a relatively high pressure gradient between the Azores High and the Icelandic Low yields a positive NAO index, a low gradient to a negative NAO index. Although its influence has been studied primarily for the winter season, the NAO is associated with considerable monthly and interannual variability and effects have been identified for all seasons. During August 2001, the mean NAO index was 0.3 (source ftp://ftp.ncep.noaa.gov/ pub/cpc/wd52dg/data/indices/tele_index.nh).

In summer the Intertropical Convergence Zone (ITCZ) and the Azores High shift toward higher latitudes. This anticyclone in combination with eastward moving low pressure systems over Central Europe lead to westerly flow in the lower and middle atmosphere toward the eastern Mediterranean area. Spreading of the high pressure across Central Europe diminishes the westerly flow and mostly air from easterly or northerly directions respectively is transported into the Mediterranean region. In the upper troposphere air masses are transported by the upper level westerlies toward the Mediterranean.

During spring and summer the Asian continent begins to heat up, developing a heat low over northern India, Pakistan and Iran that causes the ITCZ to move north, generating the Indian monsoon, with intense deep convection. A semipermanent anticyclone is located over the surface heat low, the Tibetan High. The Tropical Easterly Jet (TEJ) stream is an inherent feature of the Indian summer monsoon. It is a belt of strong easterly winds, which is part of the southern periphery of the upper tropospheric anticyclone. This TEJ between 200 and $100 \mathrm{hPa}$ transports air from Asia over North-Africa and, aided by the upper tropospheric anticyclone over the Arabian Peninsula, toward the eastern Mediterranean. Under the influence of the subtropical jetstream and the westerlies the air is subsequently transported back east over the Asian continent.

During the summer months the Mediterranean area is directly under the descending branch of the Hadley circulation, which is driven by deep convection in the ITCZ. In the upper troposphere, poleward moving air from the ITCZ is deflected by the Coriolis force. The resulting eastward flow reaches a maximum strength in the subtropical jetstream at about $40^{\circ}$ in summer, north of the Mediterranean. As a result of 
subsidence, the region is characterized by cloud-free conditions with high solar radiation intensity. Over land, convection can develop, which is generally not very deep at coastal locations. The air near the surface returns to the equatorial region in the trade winds, gathering moisture over the sea.

In summer teleconnections are found between the Mediterranean region and the South-Asian monsoon and Sahel rainfall regimes on an interannual time-scale (Ward, 1992). The sea level pressure over the eastern Mediterranean is anticorrelated with that in the Indian monsoon, mainly in the July-September period, while that in the western Mediterranean is positively correlated with a maximum during September-November. The meridional wind component is anticorrelated with the Indian monsoon over the central and eastern Mediterranean basin. This means that a more active monsoon is connected with lower sea level pressure over the eastern basin and higher over the western basin, and stronger northerly wind over most of the Mediterranean.

\section{Modeling tools}

\subsection{Backward trajectories}

The trajectories are computed with the FLEXTRA trajectory model (Stohl et al., 1995; Stohl and Seibert, 1998). Stohl and Seibert (1998), studying potential vorticity conservation, have shown that three-dimensional trajectories are more accurate than all other types, including isentropic trajectories. Thus three-dimensional trajectories were used throughout this study. In addition to the trajectory positions, FLEXTRA also provides other information, such as potential vorticity $(\mathrm{PV})$, which is interpolated from grid point values. $\mathrm{PV}$ is given in PVU (1 PVU $=1 \mathrm{PV}$ unit $=10^{-6} \mathrm{~m}^{2} \mathrm{~s}^{-1} \mathrm{~K} \mathrm{~kg}^{-1}$ ). The positions of all parcels are given every $30 \mathrm{~min}$.

As input data, three-dimensional wind fields from the European Centre for Medium-Range Weather Forecasts (ECMWF) analyses are used. For this study a horizontal resolution of $2.0^{\circ}$ and a nested domain (latitude range: $15^{\circ}$ to $75^{\circ}$, longitude range: $-30^{\circ}$ to $70^{\circ}$ ) of $0.5^{\circ}$ were employed. It has to be mentioned that the computed position of the trajectories, especially of those trajectories that have a temporal range of several days, is dependent on the resolution of the wind data. This results from the fact that the wind fields are archived every $6 \mathrm{~h}$ and consequently this data has to be interpolated in time and in space. The calculations are sensitive to initial conditions in the sense that a trajectory can separate rapidly from another trajectory starting nearby (in time or space). As a consequence, uncertainties in the origin of 5-day back trajectories can add up to several hundreds of kilometers, even using the latest high-resolution global meteorological analyses (Stohl, 1998).

To determine the source regions of the air masses which were sampled during the MINOS campaign, 5-day

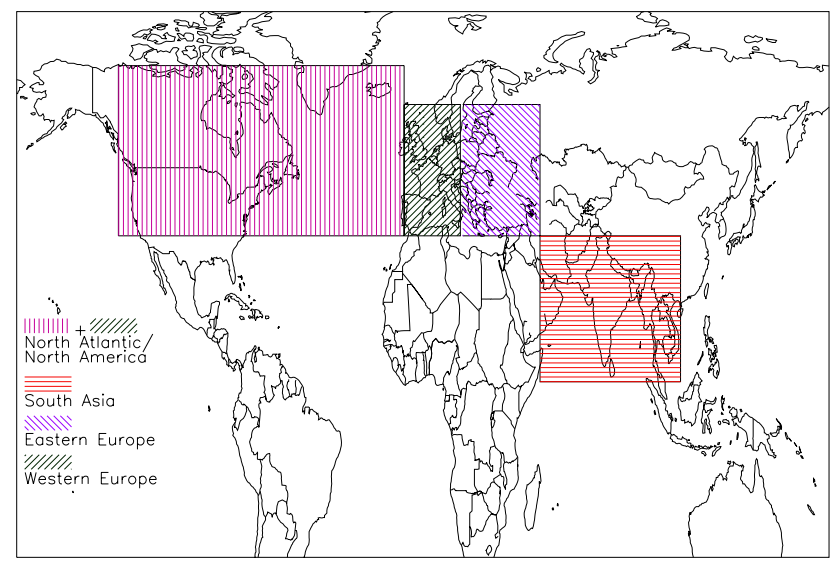

Fig. 2. Source regions of the trajectories during the MINOS campaign.

backward-trajectories were computed. Trajectories were initialized at every minute along the Falcon flight tracks.

We divided the atmosphere into four different height intervals: level one from the ground up to $2 \mathrm{~km}$, level two from 2 to $4 \mathrm{~km}$, level 3 from 4 to $8 \mathrm{~km}$ and level 4 from 8 to about $14 \mathrm{~km}$. These levels refer to the flight altitude of the Falcon aircraft during the measurements, i.e., the initialization points of the back trajectories. This implies, for example, that all trajectories with initialization points between 4 and 8 $\mathrm{km}$ are attributed to one height level regardless of altitude 5 days earlier.

\subsection{Mean trace gas mixing ratios}

The temporal resolution of the measurement of the different gases was not unique. To compute mean concentrations for the trajectory clusters, the measured values were converted to one minute averages. Hence the gas concentrations could be assigned to the corresponding trajectories, which also have a temporal resolution of one minute.

\section{Source regions}

On first inspection of all back trajectories computed for the MINOS campaign period we visually identified four main clusters of trajectories. Therefore we defined each of these clusters to represent a source region. These are: 1) western Europe; 2) eastern Europe; 3) the North Atlantic region and North America; and 4) South Asia. These regions are depicted in Fig. 2. It should be mentioned that especially for the middle and upper tropospheric trajectories the expression "source region" is debatable. Often the trace gases in these air parcels do not have their origin in the particular region depending on whether the trace gas life time exceeds that of the trajectory. Some trace gases are moreover chemically formed from precursor gases that are emitted elsewhere. In this study we nevertheless adopted this expression to distin- 
Table 1. Approximate lifetime of the sampled trace gases during summer

\begin{tabular}{ll}
\hline $\mathrm{HCHO}$ & hours \\
$\mathrm{NO}_{x}$ & days \\
$\mathrm{NO}_{\mathrm{y}}$ & days to weeks \\
$\mathrm{O}_{3}$ & days to weeks \\
$\mathrm{CH}_{3} \mathrm{COCH}_{3}$ & weeks to months \\
$\mathrm{PAN}$ & weeks to months \\
$\mathrm{CO}$ & weeks to months \\
$\mathrm{CH}_{3} \mathrm{OH}$ & months \\
$\mathrm{CH}_{3} \mathrm{CN}$ & months \\
$\mathrm{CH}_{4}$ & years \\
$\mathrm{CO}_{2}$ & years \\
\hline
\end{tabular}

Table 2. Comparison of mean concentrations for height level 1 (0-2 $\mathrm{km}$ ) for western Europe and eastern Europe trajectories

\begin{tabular}{lllll}
\hline & \multicolumn{2}{c}{ western Europe } & \multicolumn{2}{c}{ eastern Europe } \\
\hline & Mean & Std Dev & Mean & Std Dev \\
\hline $\mathrm{NO}$ & 0.04 & 0.01 & 0.05 & 0.02 \\
$\mathrm{NO}_{\mathrm{y}}$ & 1.1 & 0.5 & 1.4 & 0.4 \\
$\mathrm{HCHO}$ & 0.9 & 0.2 & 1.3 & 0.4 \\
$\mathrm{O}_{3}$ & 58 & 5 & 70 & 6 \\
$\mathrm{CH}_{3} \mathrm{OH}$ & 1426 & 411 & 3169 & 808 \\
$\mathrm{CH}_{3} \mathrm{CN}$ & 136 & 25 & 203 & 31 \\
$\mathrm{CH}_{3} \mathrm{COCH}$ & 1953 & 276 & 2755 & 435 \\
$\mathrm{PAN}_{\mathrm{CO}}$ & 324 & 99 & 627 & 224 \\
$\mathrm{CO}_{2}$ & 359 & 3 & 358 & 3 \\
$\mathrm{CH}_{4}$ & 126 & 17 & 156 & 23 \\
& 1873 & 21 & 1883 & 29
\end{tabular}

$\mathrm{NO}, \mathrm{NO}_{y}, \mathrm{HCHO}, \mathrm{O}_{3}, \mathrm{CO}, \mathrm{CH}_{4}$ in ppbv, $\mathrm{CO}_{2}$ in ppmv, $\mathrm{CH}_{3} \mathrm{OH}, \mathrm{CH}_{3} \mathrm{CN}, \mathrm{CH}_{3} \mathrm{COCH}_{3}$, PAN in pptv.

guish the different clusters. For the approximate lifetimes of the sampled trace gases see Table 1.

By definition, if an air parcel trajectory resides over a defined region it is added to the particular cluster. Often it appears that the back trajectories reside over two or more defined regions. In this case the residence time of the air parcel above the regions is the decisive point. In this study a minimum residence time of 2.75 days is used to assign such trajectories to their source region. It is thus assumed that during this period the air mass has adopted the chemical characteristics of this region. If a trajectory does not fulfil this criterion for any region it is declared as "non-defined" and is not further considered. As a result, 184 of the 2690 computed back trajectories $(6.8 \%)$ were disregarded.

\subsection{Ground $-2 \mathrm{~km}$}

Using the criteria described above we distinguish between air masses from western Europe, notably France, Germany and northern Italy, and from eastern Europe. These two clusters
Table 3. Comparison of eastern Europe mean concentrations at height level $1(0-2 \mathrm{~km})$ of trajectories originating in the free troposphere and in the boundary layer.

\begin{tabular}{lllll}
\hline & \multicolumn{2}{c}{ free troposphere } & \multicolumn{2}{c}{ boundary layer } \\
\hline & Mean & Std Dev & Mean & Std Dev \\
\hline $\mathrm{NO}$ & 0.05 & 0.04 & 0.04 & 0.03 \\
$\mathrm{NO}_{\mathrm{y}}$ & 1.4 & 0.4 & 1.4 & 0.5 \\
$\mathrm{HCHO}$ & 1.3 & 0.4 & 1.2 & 0.3 \\
$\mathrm{O}_{3}$ & 70 & 5 & 69 & 5 \\
$\mathrm{CH}_{3} \mathrm{OH}$ & 3089 & 782 & 3460 & 828 \\
$\mathrm{CH}_{3} \mathrm{CN}$ & 199 & 31 & 216 & 24 \\
$\mathrm{CH}_{3} \mathrm{COCH}$ & 2680 & 386 & 3024 & 512 \\
$\mathrm{PAN}_{\mathrm{CO}}$ & 632 & 230 & 593 & 178 \\
$\mathrm{CO}_{2}$ & 358 & 3 & 359 & 4 \\
$\mathrm{CH}_{4}$ & 161 & 20 & 167 & 17 \\
& 1880 & 31 & 1894 & 30
\end{tabular}

$\mathrm{NO}, \mathrm{NO}_{y}, \mathrm{HCHO}, \mathrm{O}_{3}, \mathrm{CO}, \mathrm{CH}_{4}$ in ppbv, $\mathrm{CO}_{2}$ in ppmv, $\mathrm{CH}_{3} \mathrm{OH}, \mathrm{CH}_{3} \mathrm{CN}, \mathrm{CH}_{3} \mathrm{COCH}_{3}$, PAN in pptv.

are shown in Fig. 3a and 3b. 176 trajectories were counted for the western region. That is about $22 \%$ of all trajectories at this height level. 595 trajectories (about 74\%) from the eastern area were registered. The remaining $4 \%$ was ignored as being "non-defined". The mean gas concentrations of the eastern and western Europe trajectories are listed in Table 2.

It can be seen that all trajectories with source regions in eastern Europe are associated with higher mean concentrations than those from westerly directions, except for $\mathrm{CO}_{2}$. In particular the mean value of PAN is nearly twice as high $(627 \pm 224$ and $324 \pm 99$ pptv). The values of acetone $(2755 \pm 435$ and $1953 \pm 276$ pptv), acetonitrile $(203 \pm 31$ and $136 \pm 25$ pptv), especially methanol (3169 \pm 808 and $1426 \pm 411$ pptv) but also $\mathrm{O}_{3}(70 \pm 6$ and $58 \pm 5)$ and $\mathrm{CO}$ $(156 \pm 23$ and $126 \pm 17)$ are significantly higher in eastern European air.

Fig. 4 depicts the temporal height development of the western European trajectories. Two thirds originate at altitudes lower than $2 \mathrm{~km}$ and mostly do not change altitude much toward the Mediterranean, except a few which are uplifted by low pressure systems over the Atlantic. The remaining one third of these trajectories originates in the free troposphere and descends in the following days toward the Mediterranean region. Likewise about one third of the eastern Europe trajectories originates in the free troposphere (see Fig. 4b). We differentiated trajectories originating on the one hand in the free troposphere and on the other hand in the boundary layer, listing the associated mean concentrations in Table 3 for eastern Europe and Table 4 for western Europe.

Although for both western and eastern Europe the boundary layer trajectories are mostly associated with higher concentrations, the differences are generally small. We hypothesize that the lower about $4 \mathrm{~km}$ are generally well mixed by 
Table 4. Same as Table 3, but for western Europe trajectories

\begin{tabular}{lllll}
\hline & \multicolumn{2}{c}{ free troposphere } & \multicolumn{2}{c}{ boundary layer } \\
\hline & Mean & Std Dev & Mean & Std Dev \\
\hline $\mathrm{NO}$ & 0.03 & 0.02 & 0.08 & 0.07 \\
$\mathrm{NO}_{\mathrm{y}}$ & 1.0 & 0.4 & 1.4 & 0.6 \\
$\mathrm{HCHO}$ & 0.9 & 0.3 & 1.0 & 0.1 \\
$\mathrm{O}_{3}$ & 59 & 5 & 61 & 6 \\
$\mathrm{CH}_{3} \mathrm{OH}$ & 1462 & 469 & 1365 & 322 \\
$\mathrm{CH}_{3} \mathrm{CN}$ & 129 & 24 & 147 & 23 \\
$\mathrm{CH}_{3} \mathrm{COCH}$ & 1896 & 234 & 2046 & 317 \\
$\mathrm{PAN}_{\mathrm{CO}}$ & 315 & 109 & 340 & 74 \\
$\mathrm{CO}_{2}$ & 358 & 3 & 359 & 3 \\
$\mathrm{CH}_{4}$ & 124 & 15 & 133 & 19 \\
& 1862 & 19 & 1881 & 28
\end{tabular}

$\mathrm{NO}, \mathrm{NO}_{y}, \mathrm{HCHO}, \mathrm{O}_{3}, \mathrm{CO}, \mathrm{CH}_{4}$ in ppbv, $\mathrm{CO}_{2}$ in ppmv, $\mathrm{CH}_{3} \mathrm{OH}, \mathrm{CH}_{3} \mathrm{CN}, \mathrm{CH}_{3} \mathrm{COCH}_{3}$, PAN in pptv.

Table 5. Comparison of western and eastern Europe trajectories at height level $2(2-4 \mathrm{~km})$

\begin{tabular}{lllll}
\hline & \multicolumn{2}{c}{ western Europe } & \multicolumn{2}{c}{ eastern Europe } \\
\hline & Mean & Std Dev & Mean & Std Dev \\
\hline $\mathrm{NO}$ & 0.04 & 0.03 & 0.02 & 0.01 \\
$\mathrm{NO}_{\mathrm{y}}$ & 0.7 & 0.3 & 0.9 & 0.2 \\
$\mathrm{HCHO}$ & 0.4 & 0.2 & 0.7 & 0.2 \\
$\mathrm{O}_{3}$ & 73 & 13 & 73 & 8 \\
$\mathrm{CH}_{3} \mathrm{OH}$ & 1614 & 602 & 2195 & 586 \\
$\mathrm{CH}_{3} \mathrm{CN}$ & 176 & 33 & 180 & 26 \\
$\mathrm{CH}_{3} \mathrm{COCH}$ & 1862 & 469 & 2206 & 433 \\
$\mathrm{PAN}_{\mathrm{CO}}$ & 537 & 129 & 744 & 149 \\
$\mathrm{CO}_{2}$ & 361 & 3 & 360 & 4 \\
$\mathrm{CH}_{4}$ & 99 & 11 & 112 & 15 \\
& 1837 & 18 & 1839 & 20
\end{tabular}

$\mathrm{NO}, \mathrm{NO}_{y}, \mathrm{HCHO}, \mathrm{O}_{3}, \mathrm{CO}, \mathrm{CH}_{4}$ in ppbv, $\mathrm{CO}_{2}$ in ppmv, $\mathrm{CH}_{3} \mathrm{OH}, \mathrm{CH}_{3} \mathrm{CN}, \mathrm{CH}_{3} \mathrm{COCH}_{3}$, PAN in pptv.

shallow convection over southern Europe, as evident from satellite images during MINOS. Many of these small-scale convective events are probably not resolved in the ECMWF analysis used to compute the trajectories.

Acetonitrile can be used as a unique tracer for biomass burning (Holzinger et al., 1999). Accordingly the mean gas concentrations suggest more biomass burning in eastern compared to western Europe during the MINOS campaign. Figure 5 shows a map with the registered nighttime fires in eastern Europe in August, 2001. In western Europe no fires have been registered for this period. Many of the computed trajectories of the eastern Europe cluster moved over the region with a high density of fires north of the Black Sea (see Fig. 3b), explaining the enhanced concentration of biomass burning tracers.
Table 6. Comparison of eastern Europe mean concentrations at height level $2(2-4 \mathrm{~km})$ of trajectories originating in the free troposphere and in the boundary layer

\begin{tabular}{lllll}
\hline & \multicolumn{2}{c}{ free troposphere } & \multicolumn{2}{c}{ boundary layer } \\
\hline & Mean & Std Dev & Mean & Std Dev \\
\hline $\mathrm{NO}$ & 0.02 & 0.01 & 0.02 & 0.01 \\
$\mathrm{NO}_{\mathrm{y}}$ & 0.9 & 0.3 & 0.9 & 0.2 \\
$\mathrm{HCHO}$ & 0.7 & 0.3 & 0.7 & 0.1 \\
$\mathrm{O}_{3}$ & 72 & 8 & 75 & 9 \\
$\mathrm{CH}_{3} \mathrm{OH}$ & 2143 & 561 & 2439 & 694 \\
$\mathrm{CH}_{3} \mathrm{CN}$ & 176 & 25 & 198 & 23 \\
$\mathrm{CH}_{3} \mathrm{COCH}$ & 2190 & 432 & 2284 & 428 \\
$\mathrm{PAN}_{\mathrm{CO}}$ & 749 & 155 & 718 & 104 \\
$\mathrm{CO}_{2}$ & 361 & 4 & 360 & 4 \\
$\mathrm{CH}_{4}$ & 109 & 12 & 121 & 19 \\
& 1839 & 20 & 1838 & 21
\end{tabular}

$\mathrm{NO}, \mathrm{NO}_{y}, \mathrm{HCHO}, \mathrm{O}_{3}, \mathrm{CO}, \mathrm{CH}_{4}$ in ppbv, $\mathrm{CO}_{2}$ in ppmv, $\mathrm{CH}_{3} \mathrm{OH}, \mathrm{CH}_{3} \mathrm{CN}, \mathrm{CH}_{3} \mathrm{COCH}_{3}$, PAN in pptv.

Table 7. Mean concentrations of the North Atlantic region between 4 and $8 \mathrm{~km}$

\begin{tabular}{lll}
\hline & Mean & Std Dev \\
\hline $\mathrm{NO}$ & 0.03 & 0.02 \\
$\mathrm{NO}_{\mathrm{y}}$ & 0.6 & 0.2 \\
$\mathrm{HCHO}$ & 0.3 & 0.1 \\
$\mathrm{O}_{3}$ & 72 & 12 \\
$\mathrm{CH}_{3} \mathrm{OH}$ & 1014 & 441 \\
$\mathrm{CH}_{3} \mathrm{CN}$ & 159 & 26 \\
$\mathrm{CH}_{3} \mathrm{COCH}$ & 1549 & 376 \\
$\mathrm{PAN}_{\mathrm{CO}}$ & 447 & 146 \\
$\mathrm{CO}_{2}$ & 366 & 3 \\
$\mathrm{CH}$ & 83 & 11 \\
\hline
\end{tabular}

$\mathrm{NO}, \mathrm{NO}_{y}, \mathrm{HCHO}, \mathrm{O}_{3}, \mathrm{CO}, \mathrm{CH}_{4}$ in ppbv, $\mathrm{CO}_{2}$ in ppmv, $\mathrm{CH}_{3} \mathrm{OH}, \mathrm{CH}_{3} \mathrm{CN}, \mathrm{CH}_{3} \mathrm{COCH}_{3}$, PAN in pptv.

\section{$5.2 \quad 2-4 \mathrm{~km}$}

The situation for the height interval between 2 and $4 \mathrm{~km}$ is very similar to the first level. There are also two main regions from where the air was transported toward the Mediterranean area, one from westerly and one from easterly directions. From the west 75 trajectories $(23 \%)$ were counted, from the east $201(62 \%)$. The remaining 15\% was associated with other regions. Figures $3 \mathrm{c}$ and $3 \mathrm{~d}$ show the associated 5-day back trajectories. It is notable that the eastern trajectories at this height level 5 days previously do not originate as far north as at the height level below. In this case they originate especially over Turkey, Greece, Bulgaria and the Ukraine. Nevertheless the difference in the mean gas concen- 
(a)

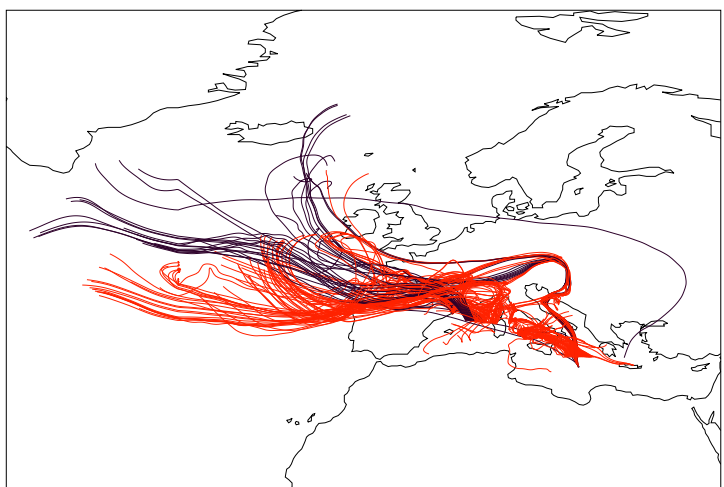

(c)

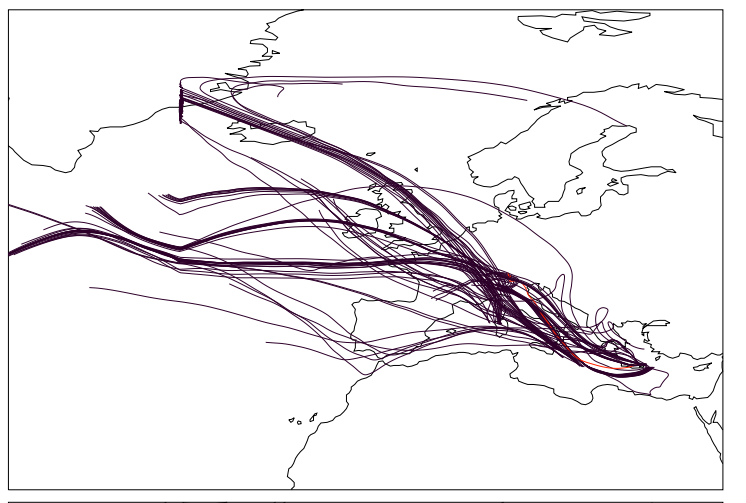

(e)

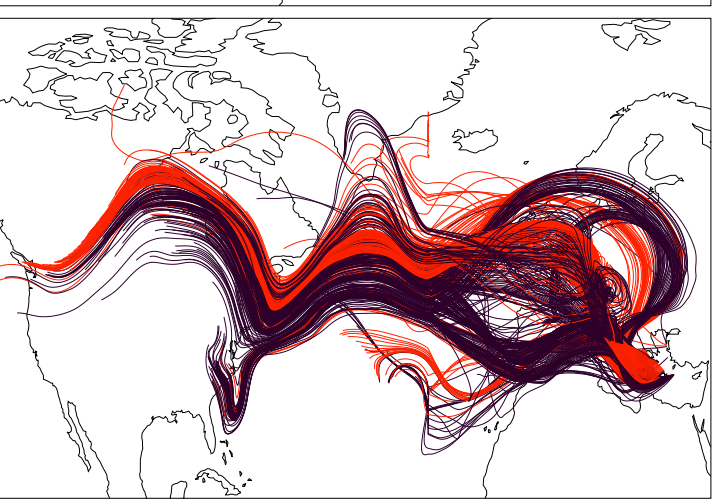

(b)

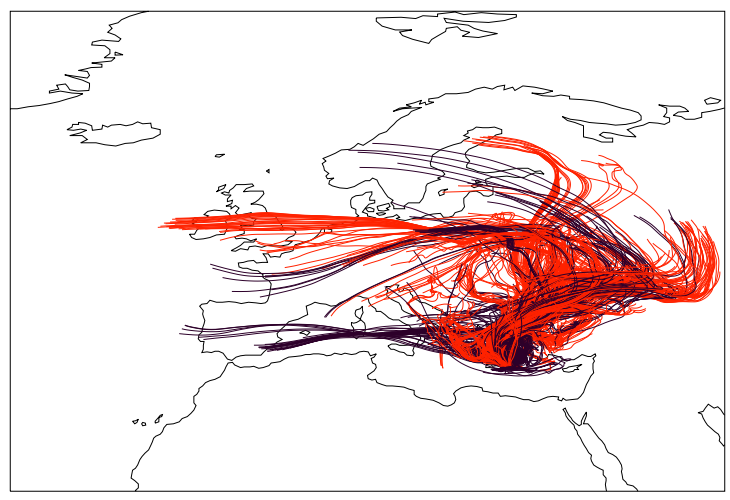

(d)

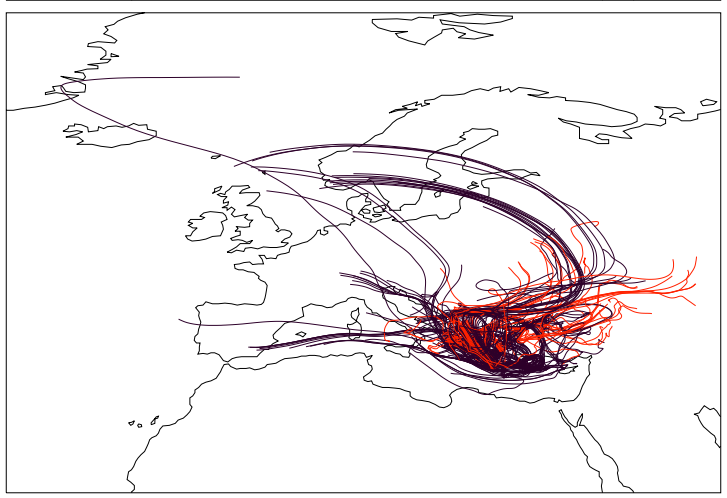

(f)

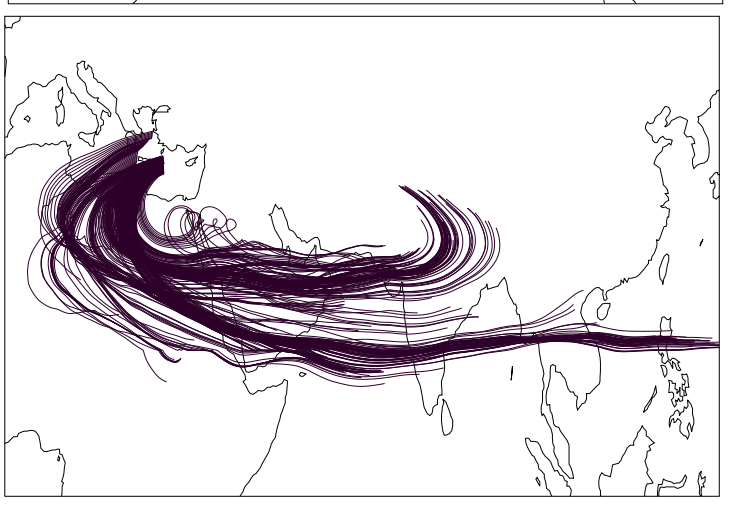

Fig. 3. Clusters of 5-day back trajectories for different height levels. (a) Western Europe trajectories between the ground and $2 \mathrm{~km}$, (b) same height level for eastern Europe trajectories, (c) same as (a) but between 2 and 4km, (d) same as (b) but between 2 and $4 \mathrm{~km}$, (e) North Atlantic/North American trajectories between 8 and 14km, (f) same as (e) but for the South Asian cluster. The red marking in (a) to (d) indicates trajectories passing through the planetary boundary layer, in (e) stratospheric trajectories.

trations (see Table 5) of these western and eastern trajectories is qualitatively similar to level 1 . Whereas nearly all western Europe trajectories originate in the free troposphere between about 4 and $9 \mathrm{~km}$, at least about $25 \%$ of the eastern Europe trajectories originate in the boundary layer (see Fig. 4c and Fig. 4d). The remaining $75 \%$ associated with altitudes up to $8 \mathrm{~km}$ descend during transport toward the Mediterranean.

Also for this height interval we obtain differences in the mean gas concentrations between western and eastern Europe air masses. Comparable to the height level below the mean gas concentrations of the eastern Europe trajectories are higher, with the exception of $\mathrm{CH}_{4}$ (west: $1837 \pm 18$ ppbv, east: $1839 \pm 20$ ppbv), $\mathrm{CO}_{2}$ (west: $361 \pm 3$ ppmv, east: $360 \pm 4$ ppmv) and $\mathrm{O}_{3}$ (west: $73 \pm 13$ ppbv, east: $73 \pm 8$ ppbv). Only the mean NO concentration is higher for the western Europe air masses (west: $0.04 \pm 0.03$ ppbv, east: $0.02 \pm 0.01 \mathrm{ppbv}$ ).

As mentioned in the previous section the enhanced mean concentration of the biomass burning tracer acetonitrile, as well as methanol, acetone and $\mathrm{CO}$, can be traced to the large number of fires north of the Black Sea (Holzinger et al., 2003).

In Table 6 the differences of the mean concentrations in the eastern Europe air mass according to their height are shown. Comparable to the level below the lowest layer is most strongly affected by fresh emissions, although the differences are generally small. 
(a)

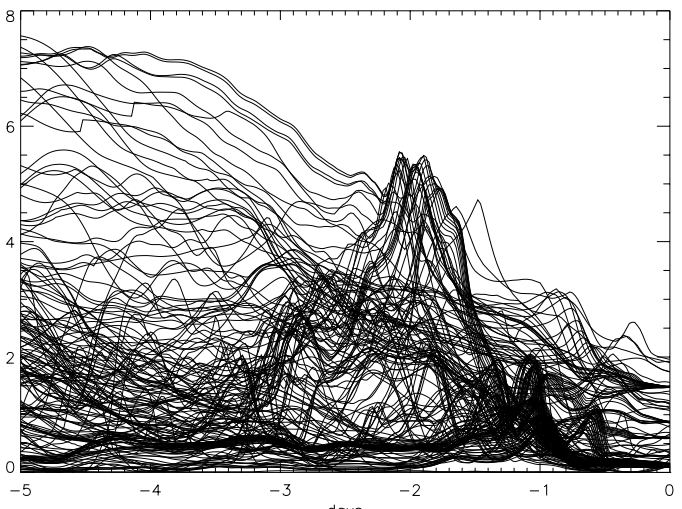

(c)
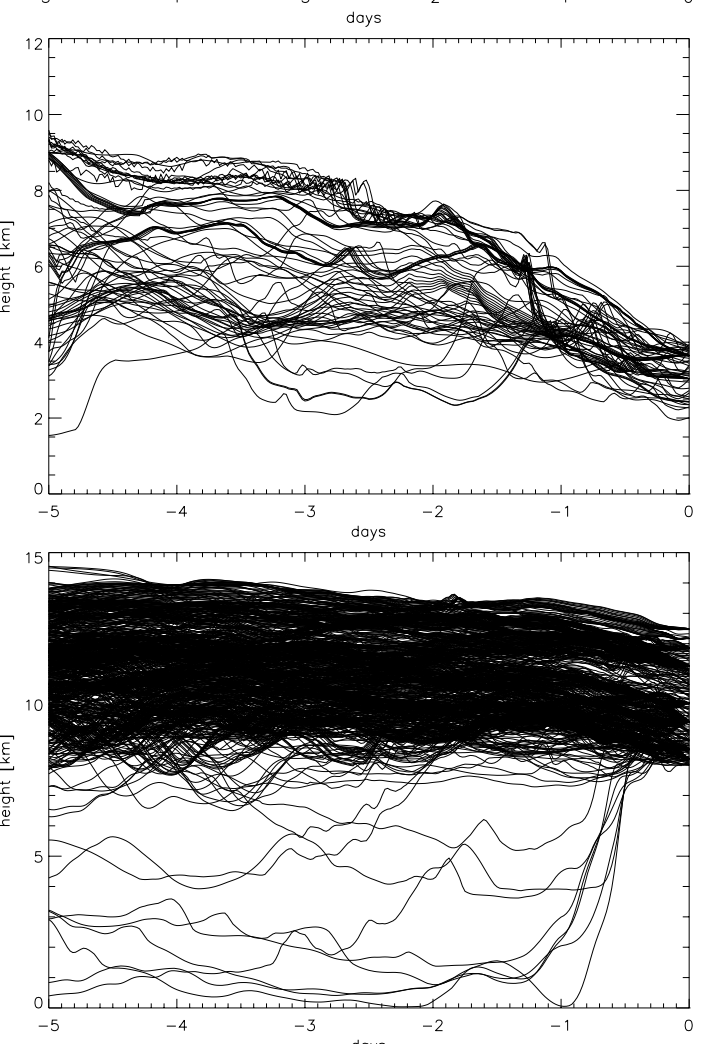

(d)

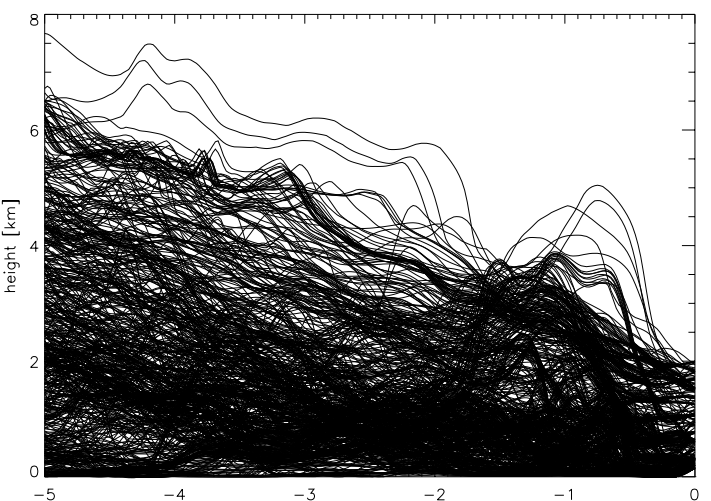

(b)

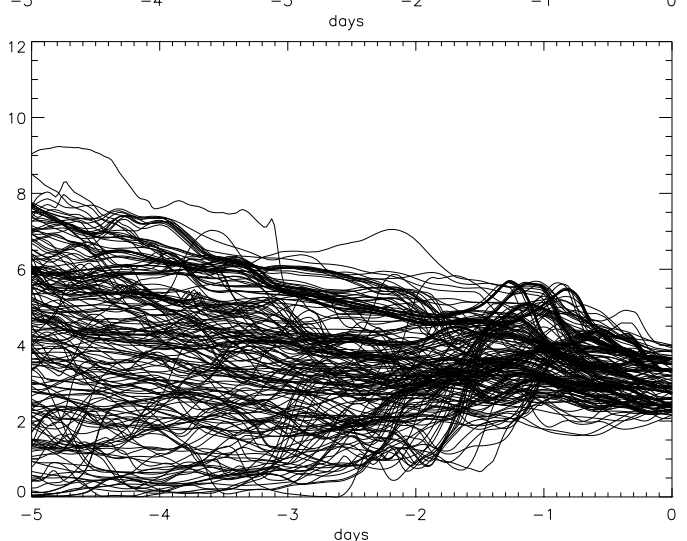

(f)

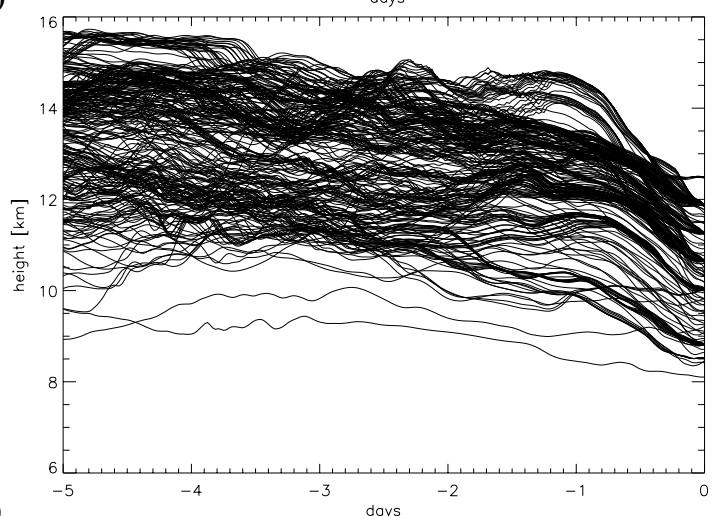

Fig. 4. Altitude versus time of the 5-day cluster back trajectories. (a) Western Europe trajectories between the ground and $2 \mathrm{~km}$, (b) same height level for eastern Europe trajectories, (c) same as (a) but between 2 and 4km, (d) same as (b) but between 2 and $4 \mathrm{~km}$, (e) North Atlantic/North American trajectories between 8 and 14km, (f) same as (e) but for the South Asian cluster.

\section{$5.3 \quad 4-8 \mathrm{~km}$}

A large fraction, i.e. 406 of the total number of 509 computed trajectories ending between 4 and $8 \mathrm{~km}$ altitude, originates from the North Atlantic/North America region (80\%). The remaining $20 \%$ is associated with other source regions. Because the number of trajectories from these regions is very low, we did not compare trace gas concentrations of different clusters at this height. Nevertheless, in Table 7 the mean concentrations for the trace gas concentrations of the NANA cluster are listed to compare these with the NANA region values of the height interval aloft.

\section{$5.4 \quad 8-14 \mathrm{~km}$}

At this height interval two main directions appear from where the air is transported toward the Mediterranean area. Most of the air originates from the west. For these trajectories (see Fig. 3e), there seems to be a coherent cluster at the west of Africa. By computing these back trajectories for more than 5 days it can be shown that they also have their source region over North America. A separate analysis of the gas concentrations of this cluster moreover shows no significant differences with the rest of the trajectories shown in Fig. 3e. Therefore all these trajectories are treated as one cluster. On 


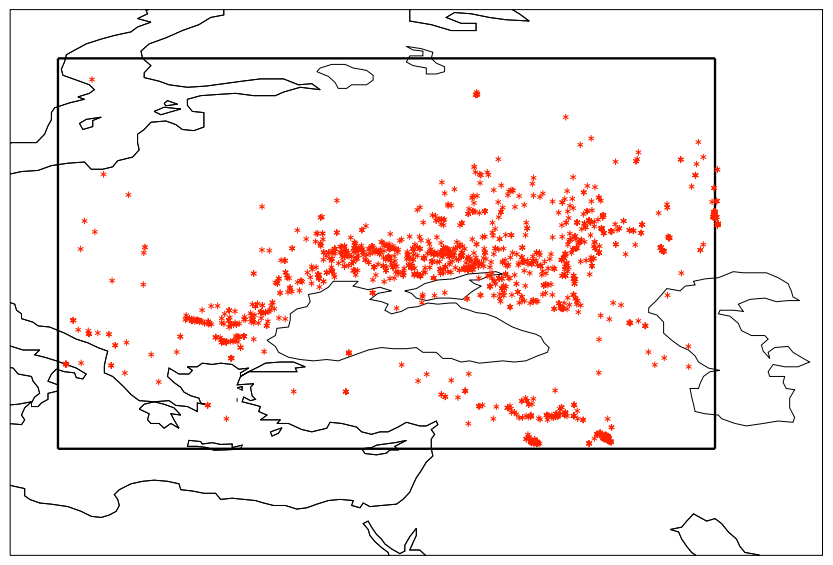

Fig. 5. Fires detected during nighttime for eastern Europe in August, 2001. The region defined as eastern Europe is outlined with the inner box. Source: ATSR World Fire Atlas http://shark1.esrin. esa.it/ionia/FIRE/AF/ATSR/.

Table 8. Comparison of mean concentrations of North Atlantic region (NANA) and South Asian trajectories mean concentrations between 8 and $14 \mathrm{~km}$. For the NANA cluster only tropospheric trajectories are considered.

\begin{tabular}{lllll}
\hline & \multicolumn{2}{c}{ North Atlantic } & \multicolumn{2}{c}{ South Asia } \\
\hline & Mean & Std Dev & Mean & Std Dev \\
\hline $\mathrm{NO}$ & 0.1 & 0.1 & 0.1 & 0.1 \\
$\mathrm{NO}_{\mathrm{y}}$ & 1.0 & 0.3 & 0.6 & 0.1 \\
$\mathrm{HCHO}$ & 0.4 & 0.1 & 0.6 & 0.3 \\
$\mathrm{O}_{3}$ & 81 & 16 & 57 & 6 \\
$\mathrm{CH}_{3} \mathrm{OH}$ & 946 & 413 & 1002 & 218 \\
$\mathrm{CH}_{3} \mathrm{CN}$ & 149 & 14 & 147 & 44 \\
$\mathrm{CH}_{3} \mathrm{COCH}$ & 1299 & 371 & 1101 & 126 \\
$\mathrm{PAN}$ & 324 & 114 & 148 & 44 \\
$\mathrm{CO}_{2}$ & 368 & 3 & 364 & 3 \\
$\mathrm{CO}_{\mathrm{CH}}$ & 77 & 11 & 98 & 7 \\
$\mathrm{CO}_{4} \mathrm{NO}_{y}, \mathrm{HCHO}, \mathrm{O}_{3}, \mathrm{CO}_{2} \mathrm{CH}_{4}$ in ppbv, $\mathrm{CO}_{2}$ in ppmv, \\
\multicolumn{2}{c}{$\mathrm{CH}_{3} \mathrm{OH}, \mathrm{CH}_{3} \mathrm{CN}, \mathrm{CH}_{3} \mathrm{COCH}_{3}, \mathrm{PAN}$ in pptv. }
\end{tabular}

the other hand, Fig. $3 \mathrm{f}$ consistently shows 5-day back trajectories originating over South Asia. Consequently these two very different clusters can be analyzed and compared. The number of the NANA trajectories is 645 , which is $61 \%$ of all trajectories at this height level. For the Asian cluster 271 trajectories were counted (26\%). $13 \%$ were associated with other source regions.

The North American trajectories mainly start 5 days back at heights above 8 up to $14 \mathrm{~km}$ (Fig. 4e), decreasing with altitude in time due to subsidence. Only a few trajectories originating in the lower troposphere are apparent. The geographical position of many upper tropospheric trajectories is further north, close to the jet stream, so there may be an enhanced

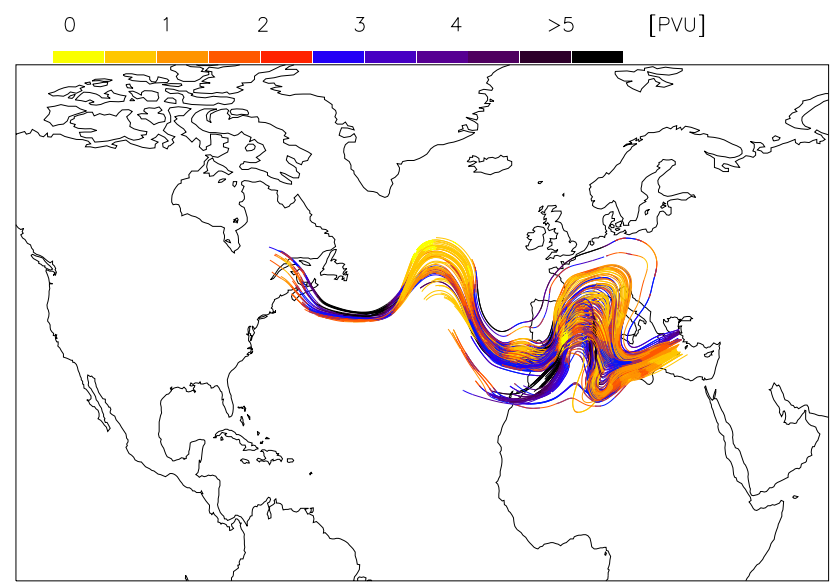

Fig. 6. Potential vorticity of a subset of the North Atlantic region trajectories. Some air parcels are temporarily associated with potential vorticity values higher than 2 PVU, indicating stratospheric influence.

possibility of mixing with stratospheric air. In Fig. 6 the PV values along a representative selection of all NANA trajectories is depicted, showing stratospheric influence along the transport paths and also over the Mediterranean, indicating that some measurements onboard the aircraft took place in the lowermost stratosphere. The Asian trajectories, starting between 9 and $16 \mathrm{~km}$ (Fig. 4f), furthermore decrease with altitude in time associated with subsidence deeper into the troposphere especially near North-Africa. The position of these trajectories is more toward the south where the tropopause is relatively high (about $16 \mathrm{~km}$ ). PV analyses of these trajectories indicates no stratospheric influence (not shown).

For comparison with the Asian air masses we removed all NANA trajectories directly influenced by the stratosphere (about 50\%). The mean gas concentrations for these two clusters are listed in Table 8. It appears that the standard deviations of the NANA cluster trace gas concentrations are partly much higher than that for South Asia, notably of acetone, methanol and PAN, signifying a much higher variability of the sources in this region, associated with a much higher geographical spread of the NANA trajectories.

In contrast to the lower height levels, none of these two clusters is clearly characterized by enhanced mean concentrations of all trace gases. Whereas $\mathrm{NO}_{\mathrm{y}}, \mathrm{O}_{3}$ and $\mathrm{CH}_{3} \mathrm{COCH}_{3}$ of the NANA sector are higher, the values of $\mathrm{HCHO}, \mathrm{CO}$, methanol and $\mathrm{CH}_{4}$ are higher for the South Asian cluster. The mean PAN concentration for that cluster is low compared with NANA. It has to be emphasized, however, that the number of trajectories associated with PAN concentrations for the Asian cluster is very limited (16). Therefore the comparison of the PAN concentrations is of limited value.

Although the stratospheric trajectories are excluded, the mean NANA ozone concentration is still higher than the Asian value. This may be caused by small-scale mixing pro- 

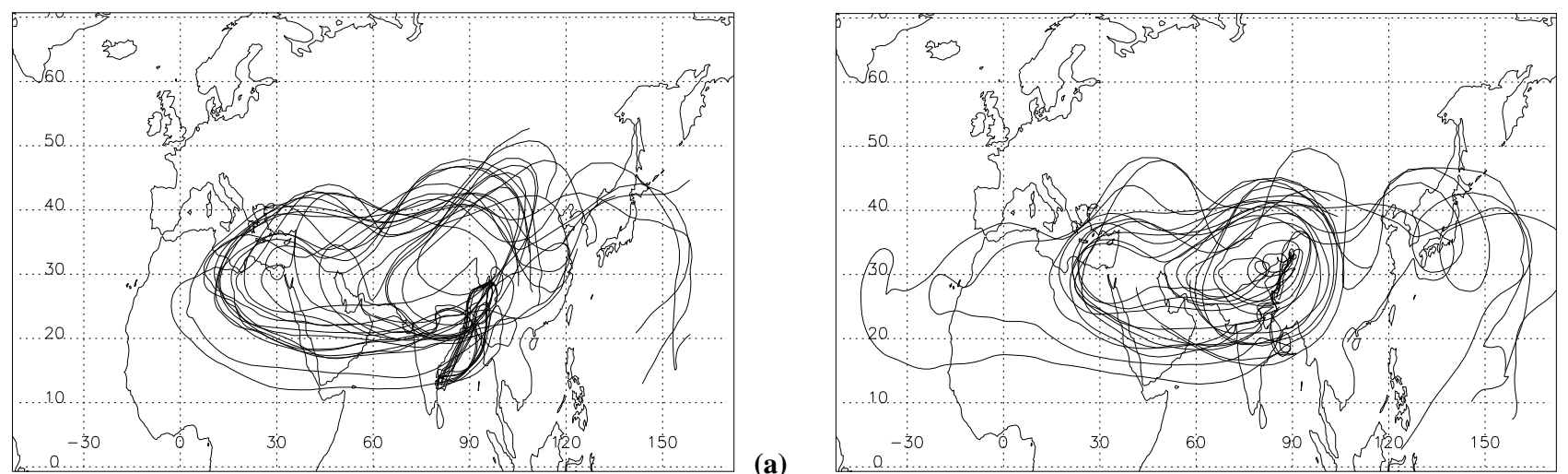

(b)
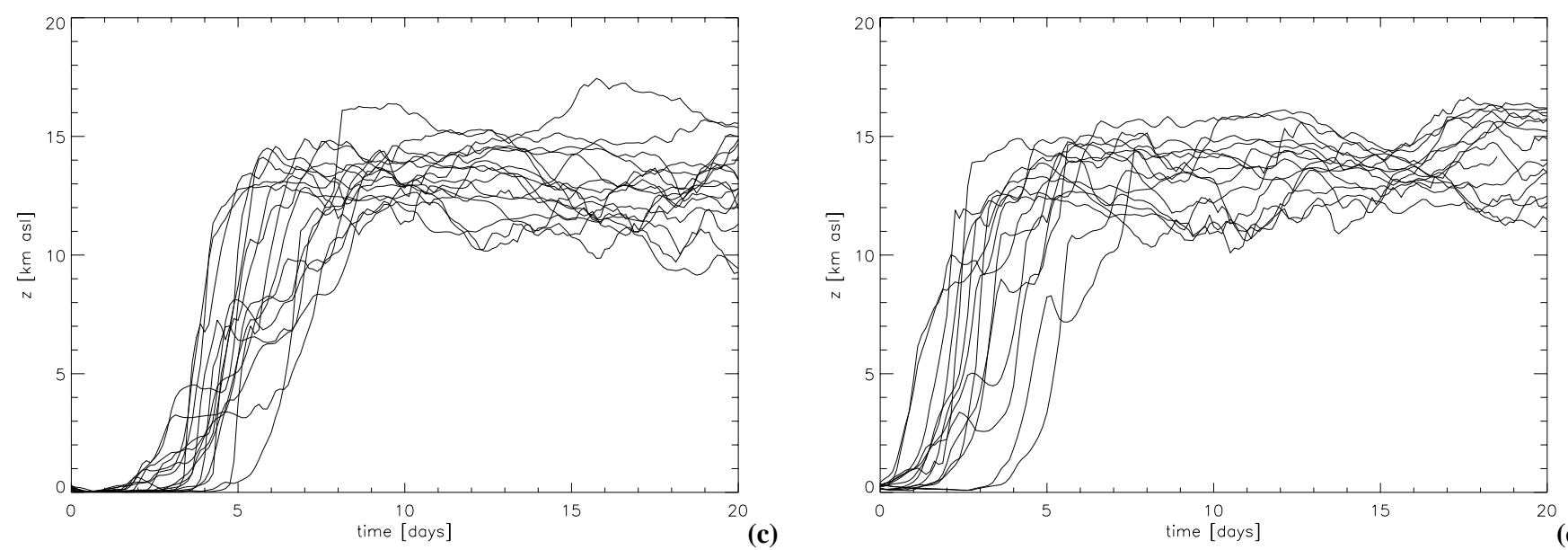

(d)

Fig. 7. 20-day forward trajectories from two large Indian cities (a) Madras (80.76E / 13.85N, SE India) and (b) Patna (85.72E / 26.01N, NE India) in July, 2001. Fig. 7c shows the temporal development of the trajectory height above sea level for the (c) Madras trajectories and (d) for those from Patna.

cesses with stratospheric air near the tropopause, which cannot be accurately simulated with trajectory models, or strong upward transport from the polluted boundary layer previous to the simulated five days.

Mean $\mathrm{CO}$ mixing ratios exceeding $80 \mathrm{ppbv}$ in the middle and upper troposphere suggest a direct continental influence (Board et al., 1999). $\mathrm{CH}_{4}$ is also enhanced in the South Asian cluster, possibly from rice cultivation. Therefore, it is likely that South Asian air pollution is transported within a few days through the Asian monsoon convection to the upper troposphere, after which it follows the upper-level anticyclone toward the eastern Mediterranean. A selection of 20-day forward trajectories, initialized each day in Juli 2001, with starting points in two West Indian cities (Madras, Patna) in Fig. 7 support this assumption. Fig. 7a and $7 \mathrm{~b}$ clearly show the anticylonic circlulation, while in Fig. $7 \mathrm{c}$ and $7 \mathrm{~d}$ the fast upward transport of the trajectories up to about $15 \mathrm{~km}$ in the monsoon convection is depicted. The duration of transport from the Indian cities to the upper troposphere over the eastern Mediterranean is about $10-15$ days. Even if the uncertainties in the origin of 20-day back-trajectories can add up to several hundreds of kilometers, these trajectories seem to be representative of transport from Indian boundary layer air. Once being transported by the strong monsoon convection into the upper troposphere ( $2-7$ days), the Tibetan High transports the air toward the Mediterranean area.

\section{Conclusions}

We have analyzed back trajectories for the MINOS campaign in August 2001 combined with measured trace gas concentrations. The goal was to find a relationship between the origin of trajectories and the observed concentration at the time of their arrival. Other articles in the present special issue of MINOS will discuss the details of trace gas sources and their chemical influences.

As determined by the large-scale atmospheric circulation, we identified "typical" flow patterns at different height levels. Between the surface and $2 \mathrm{~km}$ altitude we infer strong influences from western and eastern Europe. The same applies to the height level of 2 to $4 \mathrm{~km}$. About $74 \%$ of the computed 
trajectories at the lowest level was associated with the eastern European cluster, whereas 22\% was western European. The remaining $4 \%$ was ignored as being "non-defined". At the height of 2 to $4 \mathrm{~km}$ these values changed to about $62 \%$, $23 \%$ and $15 \%$, respectively. Whereas the air between 4 and 8 $\mathrm{km}$ mainly originated from the North Atlantic region (80\%), there was an additional strong influence above $8 \mathrm{~km}$ from South Asia. At this level about $61 \%$ of the trajectories came from the west, and $26 \%$ from South Asia. The remaining $13 \%$ was associated with other source regions.

In spite that the definition of the "source regions" is somewhat subjective and therefore open to discussion, substantial differences in the mean gas concentrations between the different clusters and hence source regions are evident.

This is especially true for the lowest two height levels. The trace gas concentrations with the eastern European 5day back trajectories were significantly higher than with the western European trajectories, signifying a higher level of air pollution. By differentiating between trajectories originating on the one hand in the boundary layer and on the other hand in the lower free troposphere, the differences in the mean gas concentrations are generally small, which can be explained by mixing in shallow convection over southern Europe.

Generally speaking the concentrations of the trace gases at the highest level (between 8 and $14 \mathrm{~km}$ ), originating from the NANA region and from South Asia, do not differ as much as at the levels below, indicating a relatively higher level of uniformity in upper tropospheric air pollution in the northern hemisphere. Nevertheless these air masses did show typical chemical characteristics. Air from the NANA source region seems to be directly influenced by the stratosphere, whereas air from South Asia, on the other hand, did not show these influences. Since $\mathrm{CO}$ and $\mathrm{CH}_{4}$ were enhanced in these air masses, we infer relatively rapid transport from the surface by strong convection in the Indian monsoon.

\section{References}

Belman, S.: The fluorimetric determination of formaldehyde, Analytica Chimica Acta, 29, 120-126, 1963.

Board, A., Fuelberg, H., Gregory, G., Heikes, B., Schultz, M., Blake, D., Dibb, J., Sandholm, S., and Talbot, R.: Chemical characteristics of air from different source regions during the Pacific Exploratory Mission-Tropics A (PEM-Tropics A), J. Geophys. Res., 104, 16 181-16 196, 1999.

Bolle, H.-J.: Mediterranean Climate, Climate, Climate Variablitity and Impacts in the Mediterranean Area: An Overview, SpringerVerlag, Berlin, 2003.

Holzinger, R., Warneke, C., Jordanm, A., Hansel, A., Lindinger, W., Scharffe, D., Schade, G., and Crutzen, P.: Biomass burning as a source of Formaldehyde, Acetaldehyde, Methanol, Acetone, Acetonitrile, and Hydrogen Cyanide, Geophys. Res. Lett., 26, 1161, 1999.

Holzinger, R., Salisbury, G., Williams, J., Klüpfel, T., de Reus, M., Traub, M., Crutzen, P.J. and Lelieveld, J.: Acetonitrile over the Eastern Mediterranean and its use for assessing the biomass burning contribution to the tropospheric burdens of $\mathrm{CO}$, acetone, methanol and PAN, Atmos. Chem. Phys. Discuss., submitted.

Kormann, R., Fischer, H., de Reus, M., Lawrence, M., Brühl, Ch., von Kuhlmann, R., Holzinger, R., Williams, J., Lelieveld, J., Warneke, C., de Gouw, J., Heland, J., Ziereis, H. and Schlager, H.: Formaldehyde over the eastern Mediterranean during MINOS: Comparison of airborne in-situ measurements with 3Dmodel results, Atmos. Chem. Phys. Discuss., 3, 1303-1331, 2003

Kouvarakis, K., Tsigaridis, K., Kanakidou, M., and Mihalopoulos, N.: Temporal variations of surface regional background ozone over Crete Island in the southeast Mediterranean, J. Geophys. Res., 105, 4399-4407, 2000.

Lelieveld, J., Berresheim, H., Borrmann, S., Crutzen, P., Dentener, F., Fischer, H., Feichter, J., Flatau, P., Heland, J., Holzinger, R., Korrmann, R., Lawrence, M., Levin, Z., Markowicz, K., Mihalopoulos, N., Minikin, A., Ramanathan, V., de Reus, M., Roelofs, G., Scheeren, H., Sciare, J., Schlager, H., Schultz, M. Siegmund, P., Steil, B., Stephanou, E., Stier, P., Traub, M., Warneke, C., Williams, J., and Ziereis, H.: Global air pollution crossroads over the Mediterranean, Science, 298, 794-799, 2002.

Lindinger, W., Hansel, A., and Jordan, A.: On-line monitoring of volatile organic compounds at pptv levels by means of ProtonTransfer-Reaction Mass Spectrometry (PTR-MS) medical applications, food control and environmental research, Int. J. Mass Spectrom. Ion Processes, 173, 1998.

Moody, J., Oltmans, S., Levy II, H., and Mertill, J.: Transport climatology of tropospheric ozone: Bermuda, 1988-1991, J. Geophys. Res., 100, 7179-7191, 1995.

Pochanart, P., Akimoto, H., Maksyutov, S., and Staehelin, J.: Surface ozone at the Swiss Alpine site Arosa: The hemispheric background and the influence of large-scale anthropogenic emissions, Atmos. Environ., 35, 5553-5566, 2001.

Schlager, H., Konopka, P., Schulte, P., Schumann, U., Ziereis, H., Arnold, F., Klemm, M., Hagen, D., Whitefield, P., and Ovarlez, J.: In situ observations of air traffic emission signatures in the North Atlantic flight corridor, J. Geophys. Res., 102, 10779 $10750,1997$.

Stohl, A.: Computation, Accuracy and Applications of Trajectories - A Review and Bibliography, Atmos. Environ., 32, 947-996, 1998.

Stohl, A. and Seibert, P.: Accuracy of trajectories as determined from the conservation of meteorological tracers, Q. J. R. Met. Soc., 125, 1465-1485, 1998.

Stohl, A., Wotawa, G., Seibert, P., and Kromp-Kolb, H.: Interpolation errors in wind fields as a function of spatial and temporal resolution and their impact on different types of kinematic trajectories, J. Ap. Me., 34, 2149-2165, 1995.

Ward, M.: Provisionally corrected surface wind data, worldwide ocean-atmosphere surface fields and Sahelian rainfall variability, J. Climate, 5, 454-475, 1992.

Wienhold, F., Fischer, H., Hoor, P., Wagner, V., Königstedt, R., Harris, G., Anders, J., Grisar, R., Knothe, M., Riedel, W., Lübken, F., and Schilling, T.: Tristar - a tracer in situ TDLAS for atmospheric research, Appl. Phys. B., 67, 411-417, 1998.

Ziereis, H., Schlager, H., Schulte, P., van Velthoven, P., and Slemr, F.: Distributions of NO, NOx, and NOy in the upper troposphere and lower stratosphere between 28 and $61^{\circ} \mathrm{N}$ during POLINAT 2, J. Geophys. Res., 105, 3653-3664, 2000. 